\title{
GAMBARAN GANGGUAN KADAR NATRIUM SERUM PADA PASIEN STROKE DI RSUP PROF. DR. R.D. KANDOU MANADO
}

\author{
Mieke A. H. N. Kembuan \\ Bagian Neurologi Fakultas Kedokteran Universitas Sam Ratulangi Manado \\ Email: dr.miekekembuan@yahoo.com
}

\begin{abstract}
World-wide, stroke is a main public health problem. It is one of the leading causes of chronic disability and death. Both hyponatremia and hypernatremia have a negative influence on the outcome of strokes. Hyponatremia is associated with increased mortality and complication rate, meanwhile hypernatremia is often found in the treatment of cerebral oedema in strokes. There are scarce data about natrium level disorders in acute strokes, especially from developing countries. This study aimed to describe the incidence of natrium disorders among acute stroke patients, and the difference of means of natrium based on the severity of the stroke and on GCS at admission. This was a hospital-based crosssectional study. Samples consisted of 82 patients that met the inclusion criteria. The data of natrium levels were obtained from the hospital medical records. The results showed that the incidence of natrium disorders among acute stroke victims was 30\%. The mean natrium level was $138.01 \mathrm{Meq} / \mathrm{L}$ (95\% CI, 135.83-140.20). The incidence of hyponatremia was $28 \%$ while hypernatremia was $2 \%$. There was no difference of mean-natrium-levels based on the severity of strokes $(P>0.05)$ and of GCS $(P>0.05)$. Conclusion: The incidence of natrium disorders among acute stroke patients was high but there was no difference between mean natrium levels based on the severity of strokes and of GCS.
\end{abstract}

Keywords: natrium, natrium level disorders, acute stroke.

\begin{abstract}
Abstrak: Stroke termasuk dalam masalah kesehatan utama di masyarakat dan merupakan penyebab utama kecacatan kronik dengan angka mortalitas tertinggi ke-2 di seluruh dunia. Baik hiponatremia maupun hipernatremia memberikan pengaruh negatif terhadap keluaran stroke. Hiponatremia meningkatkan angka kematian dan komplikasi, sedangkan hipernatremia sering terdeteksi bersamaan dengan penanganan edema serebral pada stroke. Data mengenai insidens gangguan kadar natrium pada stroke akut masih sangat kurang, terutama dari negara-negara berkembang. Penelitian ini bertujuan untuk mendapatkan insidens gangguan kadar natrium pada pasien stroke akut dan deskripsi perbedaan rerata kadar natrium pada berbagai derajat defisit neurologi dan GCS saat masuk rumah sakit. Penelitian ini bersifat potong lintang berbasis rumah sakit dengan jumlah sampel sebanyak 82 dan kriteri inklusi tertentu. Hasil penelitian memperlihatkan angka insidens gangguan kadar natrium pada stroke akut sebesar 30\%. Rerata kadar natrium $138.01 \mathrm{Meq} / \mathrm{L}$ (95\% CI, 135,83-140,20). Hiponatremia didapatkan pada 28\% kasus sedangkan hipernatremia pada $2 \%$ kasus stroke akut. Tidak terdapat perbedaan bermakna antara rerata kadar natrium berdasarkan beratnya stroke dan GCS $(P>0,05)$. Simpulan: Insidens gangguan kadar natrium pada stroke akut tinggi. Tidak terdapat perbedaan bermakna antara rerata kadar natrium berdasarkan beratnya stroke dan GCS.
\end{abstract}

Kata kunci: natrium, gangguan kadar natrium, stroke akut. 
Stroke masih merupakan masalah kesehatan utama di masyarakat. Secara global, stroke menempati ranking ke-2 pembunuh terbesar, dengan angka kecatatan yang masih tinggi. Perkiraan anggaran yang dihabiskan untuk perawatan stroke termasuk perhitungan hilangnya produktivitas akibat stroke merupakan masalah besar yang terus menunjukkan peningkatan. ${ }^{1} \mathrm{Di}$ Indonesia, bersama penyakit kardiovaskular lainnya, stroke telah menjadi salah satu pembunuh nomor satu. ${ }^{2}$ Data Departemen Kesehatan RI mengungkapkan bahwa penyebab utama kematian di seluruh rumah sakit di Indonesia ialah karena stroke. ${ }^{3}$ Di Manado, data RSUP Prof. Dr. R.D. Kandou Manado menunjukkan peningkatan kasus stroke yang dirawat. Salah satu faktor yang memperberat kondisi medik pasien stroke ialah adanya berbagai komorbititas/komplikasi yang menyertai.

Komplikasi berupa gangguan elektrolit lebih banyak ditemukan pada serangan stroke akut. $^{4}$ Gangguan kadar natrium serum merupakan kelainan elektrolit yang paling sering ditemukan dalam penyakitpenyakit neurologik, baik berupa hiponatremia maupun hipernatremia. Umumnya hipernatremia muncul dalam bentuk sindrom diabetes insipidus (DI), sedangkan hiponatremia berupa syndrome of inappropriate antidiuretic hormone (SIADH) atau cerebral salt wasting syndrome (CSW). ${ }^{5,6}$ Hiponatremia paling sering ditemukan pada penanganan pasien yang dirawat di ruang ICU. Sebagian besar penelitian mengenai gangguan elektrolit berfokus pada mekanisme neuroendokrin yang terlibat serta penanganannya. Dewasa ini, penelitian ditujukan untuk mendapatkan prevalensi, faktor risiko, hubungan dengan kondisi lain, dan parameter pengukuran. ${ }^{5}$ Walaupun gangguan elektrolit sangat penting diperhatikan dalam penanganan stroke, insidensi gangguan kadar natrium serum pada pasien stroke terutama di negara berkembang masih jarang dilaporkan.

\section{METODE PENELITIAN}

Penelitian ini bersifat desktiptif analitik dengan desain potong-lintang berbasis rumah sakit. Penelitian dilaksanakan di Bagian Neurologi RSUP Prof. Dr. R.D. Kandou Manado, terutama pada ruangan-ruangan yang menangani pasien stroke akut. Diagnosis stroke ditegakkan dari anamnesis, pemeriksaan fisik, dan dikonfirmasi dengan pemeriksaan CT-scan kepala.

Gangguan natrium serum ialah kadar natrium diluar batas normal yang ditetapkan (135-153 Meq/L). Dikategorikan hiponatremia bila kadar natrium <135 Meq/L, sedangkan hipernatremia bila kadar natrium >153 Meq/L. Defisit neurologik ringan ialah bila Neurological Institute of Health Science for Stoke (NIHSS) <4; sedang 4-15; dan berat $>15$, sedangkan untuk GCS ringan 13-15; sedang (9-12); dan berat (3-8). Populasi target ialah seluruh pasien stroke akut dengan gangguan kadar natrium. Sampel penelitian ialah seluruh pasien yang didiagnosis stroke dan memenuhi kriteria inklusi. Pengambilan sampel dilaksanakan selama bulan Februari dan Maret 2013. Kriteria inklusi ialah: 1) Pasien tidak sedang menjalani terapi diuretik; 2) Pasien tidak mengalami syok, dan menjalani resusitasi dengan cairan normal salin; dan 3) Pasien tidak memiliki riwayat penyakit ginjal atau endokrin sebelumnya. Kriteria eksklusi ialah semua pasien yang dalam perjalanan penanganan berpotensi untuk terjadi gangguan kadar natrium serum atau adanya komplikasi yang dapat memengaruhi kadar natrium serum. Sampel didapatkan melalui simple random sampling dengan melakukan pengundian pada nomor rekam medik, dan diperoleh subyek penelitian sebesar 82 pasien.

Data primer didapatkan dari hasil wawancara untuk mendapatkan data umum seperti: usia, jenis kelamin, suku, tingkat pendidikan, dan pekerjaan. Pada pasien yang tidak bisa berkomunikasi, wawancara dilakukan pada keluarga/orang terdekat. Data sekunder didapatkan dari data rekam medis pasien stroke berupa kadar natrium serum, hasil pemeriksaan NIHSS, dan gambaran brain CT-scan. Data deskriptif 
ditampilkan dalam bentuk frekuensi dan distribusi. Uji ANOVA dilakukan untuk mendapatkan hubungan antara NIHSS dan GCS dengan kadar natrium, dan dikerjakan dengan bantuan SPSS versi 17.

\section{HASIL PENELITIAN}

Dari hasil analisis didapatkan rerata usia pasien stroke akut 57,93 tahun (95\% CI 55,57-60,28; SD $\pm 10,72$ tahun). Usia termuda 36 tahun sedangkan usia tertua 82 tahun (Tabel 1).

Tabel 1. Distribusi usia pasien stroke akut

\begin{tabular}{ccccc}
\hline Variabel & Mean & SD & $\begin{array}{c}\text { Minimal- } \\
\text { maksimal }\end{array}$ & $\begin{array}{c}\mathbf{9 5 \%} \\
\text { CI }\end{array}$ \\
\hline Usia & 57,93 & 10,72 & $36-82$ & $55,57-$ \\
& & & & 60,28 \\
\hline
\end{tabular}

Distribusi kelompok usia dengan interval 10 tahun memperlihatkan distribusi yang hampir merata. Kelompok usia 51-60 tahun yang paling dominan (29\%), sedangkan kelompok usia 31-40 tahun (5\%) yang paling sedikit (Tabel 2).

Tabel 2. Distribusi pasien stroke akut berdasarkan kelompok usia

\begin{tabular}{ccc}
\hline Kelompok usia & Jumlah & Persentase \\
\hline $31-40$ & 4 & 5 \\
$41-50$ & 19 & 23 \\
$51-60$ & 24 & 29 \\
$61-70$ & 22 & 27 \\
$>70$ & 13 & 16 \\
Total & 82 & 100 \\
\hline
\end{tabular}

Berdasarkan data jenis kelamin, subyek penelitian didominasi oleh jenis kelamin perempuan (60\%) (Tabel 3).

Tabel 3. Distribusi pasien stroke akut berdasarkan jenis kelamin

\begin{tabular}{ccc}
\hline Jenis kelamin & Jumlah & Persentase \\
\hline Perempuan & 49 & 60 \\
Laki-laki & 33 & 40 \\
Total & 82 & 100 \\
\hline
\end{tabular}

Tabel 4 memperlihatkan distribusi tingkat pendidikan yang didominasi oleh pendidikan setingkat SMA (50\%), sedangkan yang paling sedikit tidak sekolah (2\%).

Tabel 4. Distribusi pasien stroke akut berdasarkan tingkat pendidikan

\begin{tabular}{ccc}
\hline Pendidikan & Jumlah & Persentase \\
\hline SD & 25 & 31 \\
SMP & 8 & 10 \\
SMA & 40 & 50 \\
PT & 7 & 7 \\
Tidak sekolah & 2 & 2 \\
Total & 82 & 100 \\
\hline
\end{tabular}

Tabel 5 memperlihatkan jenis pekerjaan terbanyak ialah ibu rumah tangga (46\%) sedangkan yang paling sedikit ialah buruh, tukang dan tidak bekerja (masing-masing $1 \%)$.

Tabel 5. Distribusi pasien stroke akut berdasarkan pekerjaan

\begin{tabular}{ccc}
\hline Pekerjaan & Jumlah & $\mathbf{\%}$ \\
\hline Buruh & 1 & 1 \\
IRT & 38 & 46 \\
Karyawan & 2 & 2 \\
Nelayan & 2 & 2 \\
Pensiunan & 5 & 6 \\
Petani & 12 & 15 \\
PNS & 10 & 12 \\
Sopir & 2 & 2 \\
Swasta & 8 & 10 \\
Tukang & 1 & 1 \\
Tiada & 1 & 1 \\
Total & 82 & 100 \\
\hline
\end{tabular}

Berdasarkan data distribusi suku pada Tabel 6 didapatkan sebagian besar pasien berasal dari suku Minahasa (76\%), diikuti oleh suku Gorontalo (10\%) dan Sangihe (9\%).

Pada penelitian ini didapatkan rerata kadar natrium pasien stroke akut 138,01 Meq/L (95\% CI 135, 83-140,20; SD \pm 10,72 Meq/L), dengan kadar natrium terendah $116 \mathrm{Meq} / \mathrm{L}$ dan kadar natrium tertinggi $170 \mathrm{Meq} / \mathrm{L}$ (Tabel 7). 
Tabel 6. Distribusi pasien berdasarkan suku

\begin{tabular}{ccc}
\hline Suku & Jumlah & Persentase \\
\hline Minahasa & 62 & 76 \\
Sangihe & 7 & 9 \\
Gorontalo & 8 & 10 \\
Bolmong & 3 & 4 \\
Jawa & 2 & 2 \\
Total & 82 & 100 \\
\hline
\end{tabular}

Tabel 7. Distribusi kadar Natrium pada pasien stroke akut

\begin{tabular}{ccccc}
\hline Variabel & Mean & SD & $\begin{array}{c}\text { Minimal- } \\
\text { maksimal }\end{array}$ & $\mathbf{9 5 \% ~ C I ~}$ \\
\hline Natrium & 138,01 & 10,72 & $116-170$ & $\begin{array}{c}135,83- \\
140,20\end{array}$ \\
\hline
\end{tabular}

Tabel 8 memperlihatkan bahwa sebagian besar pasien stroke akut memiliki kadar natrium dalam batas normal (70\%). Kasus hiponatremia didapatkan pada 28\% kasus sedangkan hipernatremia $2 \%$.

Tabel 8. Distribusi kadar natrium berdasarkan kategori

\begin{tabular}{ccc}
\hline Kategori & Jumlah & Persentase \\
\hline Hiponatremia & 23 & 28 \\
Normal & 57 & 70 \\
Hipernatremia & 2 & 2 \\
Total & 82 & 100 \\
\hline
\end{tabular}

Tabel 9 memperlihatkan gangguan natrium didapatkan pada 30\% dari keseluruhan subyek penelitian. Dengan demikian, insidens gangguan kadar natrium serum pada penelitian ini $30 \%$.

Tabel 9. Distribusi gangguan kadar natrium pada pasien stroke akut

\begin{tabular}{ccc}
\hline $\begin{array}{c}\text { Gangguan } \\
\text { natrium }\end{array}$ & Jumlah & Persentase \\
\hline Ya & 25 & 30 \\
Tidak & 57 & 70 \\
Total & 82 & 100 \\
\hline
\end{tabular}

Rerata kadar natrium pada pasien dengan defisit neurologik ringan 139,4 $\mathrm{Meq} / \mathrm{L}$ (SD \pm 9,0 Meq/L); pada pasien dengan defisit neurologik sedang 138,5 Meq/L (SD \pm 9,7 Meq/L); sedangkan pada pasien dengan defisit neurologik berat 133,0 Meq/L (SD \pm 11,9 Meq/L). Hasil uji statistik didapatkan nilai $P=0,27$ yang menunjukkan tidak terdapat perbedaan bermakna antara kadar natrium pada ketiga derajat defisit neurologik (Tabel 10).

Tabel 10. Hubungan gangguan Natrium dengan derajat defisit neurologik (NIHSS)

\begin{tabular}{ccccc}
\hline Variabel & Mean & SD & 95\% CI & P-value \\
\hline Ringan & 139,4 & 9,0 & $132,9-$ & 0,27 \\
& & & 145,8 & \\
Sedang & 138,5 & 9,7 & $136,0-$ & \\
& & & 140,9 & \\
Berat & 133,0 & 11,9 & $123,8-$ & \\
& & & 140,2 & \\
\hline
\end{tabular}

Rerata kadar natrium pada pasien dengan GCS 3-8 138,5 Meq/L (SD \pm 9,9 Meq/L); pada pasien dengan GCS 9-12 139,8 Meq/L (SD \pm 9,1 Meq/L); dan pada pasien dengan GCS 13-15 131,4 Meq/L (SD \pm 9,4 Meq/L). Hasil uji statistik memperlihatkan nilai $P=0,07$, yang berarti tidak terdapat perbedaan bermakna antara kadar natrium pada ketiga level GCS (Tabel 11).

Tabel 11. Hubungan gangguan natrium dengan GCS

\begin{tabular}{|c|c|c|c|c|}
\hline Variabel & Mean & SD & $95 \% \mathrm{CI}$ & $\begin{array}{c}P \text { - } \\
\text { value }\end{array}$ \\
\hline GCS 3-8 & 138,5 & 9,97 & $\begin{array}{c}135,8- \\
141,3\end{array}$ & 0,07 \\
\hline GCS 9-12 & 139,8 & 9,10 & $\begin{array}{c}135,5- \\
144,2\end{array}$ & \\
\hline GCS 13-15 & 131,4 & 9,46 & $\begin{array}{c}124,6- \\
138,1\end{array}$ & \\
\hline
\end{tabular}

Pada Tabel 12 terlihat hasil analisis hubungan antara gangguan kadar natrium dengan hasil brain CT-scan. Baik kadar 
natrium yang terganggu maupun yang tidak, keduanya ditemukan lebih tinggi pada pasien hasil brain CT-scan perdarahan dibandingkan pasien dengan hasil infark. Hasil uji statistik mendapatkan nilai $P=$ 0,82 yang menunjukkan bahwa tidak terdapat hubungan bermakna antara gangguan kadar natrium dengan hasil brain CT-scan.

Tabel 12. Insidens gangguan kadar natrium berdasarkan hasil brain CT-scan

\begin{tabular}{|c|c|c|c|c|c|c|}
\hline \multirow{3}{*}{$\begin{array}{c}\text { Gangguan } \\
\text { kadar } \\
\text { natrium }\end{array}$} & \multicolumn{3}{|c|}{$\begin{array}{l}\text { Hasil brain CT- } \\
\text { scan }\end{array}$} & \multirow{2}{*}{\multicolumn{3}{|c|}{$\begin{array}{c}\text { OR } \quad P- \\
\text { Total } 95 \% \text { value } \\
\text { CI }\end{array}$}} \\
\hline & Infark & & Irahan & & & \\
\hline & $\mathrm{N} \%$ & & $\%$ & $\%$ & & \\
\hline & 114 & & 56,0 & & & 0,8 \\
\hline & 27 & 30 & 52,6 & 100 & & \\
\hline & 38 46,3 & 44 & 53,7 & 82100 & & \\
\hline
\end{tabular}

\section{BAHASAN}

Insidens stroke meningkat seiring peningkatan usia. Pada penelitian ini, insidens stroke didapatkan tertinggi pada kelompok usia 51-60 tahun diikuti usia 6170 tahun (Tabel 2), dengan rerata usia pasien 57,93 tahun. Hasil ini sesuai dengan penelitian di Bangladesh yang mendapatkan insidens stroke terbanyak pada usia 51-60 tahun dan 61-70 tahun. ${ }^{7}$ Hasil penelitian Bevan et al. juga mendapatkan insidens stroke tertinggi pada kelompok usia di atas 45 tahun. ${ }^{4}$ Distribusi rerata kadar natrium berdasarkan kelompok usia terendah yaitu di atas 70 tahun (132,69 $\mathrm{Meq} / \mathrm{L})$, tetapi tidak ditemukan perbedaan bermakna antara berbagai kelompok usia yang diteliti $(P>0,05)$.

Pada penelitian ini didapatkan pasien stroke akut terbanyak pada jenis kelamin perempuan (60\%). Temuan ini berbeda dengan yang diperoleh Siddiqui et al., yaitu pasien stroke lebih banyak ditemukan pada jenis kelamin laki-laki (72\%). Beberapa studi internasional lainnya juga menemukan bahwa stroke lebih sering ditemukan pada jenis kelamin laki-laki.

Penelitian ini memperlihatkan sebagi- an besar pasien stroke berasal dari suku Minahasa (76\%). Hal ini mungkin disebabkan komposisi penduduk di Sulawesi Utara dengan mayoritas suku Minahasa. Laporan penelitian-penelitian sebelumnya juga menyatakan bahwa suku Minahasa memiliki prevalensi tinggi dari penyakit tidak menular seperti hipertensi dan diabetes melitus, ${ }^{8,9}$ yang merupakan faktor risiko utama terjadinya serangan stroke. ${ }^{2}$

Gangguan kadar natrium pada penelitian ini didapatkan sebesar 30\%; sebagian besar berupa hiponatremia (28\%). Hasil ini serupa dengan beberapa penelitian internasional yang melaporkan adanya insidens gangguan kadar natrium pada stroke akut berkisar 11-53\%; sebagian besar merupakan hiponatremia (32\%). ${ }^{4,10}$ Hipernatremia pada penelitian ini sebesar $2 \%$, yang tidak berbeda jauh dengan beberapa penelitian sebelumnya yang mendapatkan insidens sebesar 0,3-3,5\%., ${ }^{6,7}$ Aiyagari et al. ${ }^{6}$ mendapatkan insidens hipernatremia sebesar 7,9\%.

Pada penelitian ini didapatkan insidens terjadinya gangguan kadar natrium serum cukup tinggi (30\%), yang serupa dengan berbagai penelitian lainnya. Hasil penelitian ini memperlihatkan jumlah pasien cukup banyak yang mengalami gangguan kadar natrium serum bersamaan dengan terjadinya stroke. Hal ini sesuai dengan acuan pustaka yang menyatakan bahwa hiponatremia merupakan gangguan elektrolit yang terbanyak ditemukan di antara penyakit akut pada otak, dan terjadinya melalui berbagai mekanisme yang berbeda. Dari berbagai mekanisme tersebut terdapat dua kondisi yang paling sering menyebabkan terjadinya hiponatremia pada penyakit akut di otak yaitu SIADH dan CSW. ${ }^{11}$

Angka kematian pada stroke dengan hiponatremia lebih tinggi dibandingkan stroke dengan normonatremia. Keluaran yang buruk berupa kematian atau defisit neurologik yang berat terutama ditemukan pada kasus-kasus stroke, trauma, dan infeksi. $^{12}$ Huang $^{10}$ menemukan adanya hubungan antara kejadian hiponatremia pada stroke akut, terutama pada stroke iskemik pertama, dengan peningkatan risiko mortalitas dalam 3 tahun setelah 
terkena stroke. Penelitian tersebut juga mendapatkan bahwa adanya hiponatremia pada stroke akut, terutama stroke iskemik pertama, akan meningkatkan resiko terjadinya pneumonia. Kejadian hiponatremia ini berhubungan dengan adanya status diabetes melitus pada pasien stroke iskemik pertama. $^{10}$

Secara umum insidens hipernatremia pada penelitian ini sesuai dengan beberapa acuan pustaka. Aiyagari ${ }^{6}$ mendapatkan insidens hipernatremia sebesar 7,9\% dan angka kejadian ini meningkat sampai 24,3\% pada pasien-pasien yang mendapatkan terapi mannitol. Pasien yang dirawat di ICU umumnya memiliki angka kejadian hipernatremia lebih tinggi daripada yang tidak dirawat di ICU. Menurut Aiyagari ${ }^{6}$ peningkatan ini mungkin terjadi karena meningkatnya pengeluaran cairan insensibel melalui ventilasi dan demam, pemberian makanan melalui pipa nasogastrik, penurunan kesadaran, keterbatasan akses terhadap air, dan penyakit yang mendasari. Diabetes insipidus (DI) merupakan penyebab utama hipernatremia pada cedera serebral. Adanya kejadian hipernatremia merupakan faktor independen yang mengakibatkan peningkatan angka mortalitas. Komplikasi yang sering ditemukan pada hipernatremia ialah terjadinya perubahan status mental dan kejang. Umumnya, gangguan elektrolit yang sering ditemukan dan harus dideteksi ialah SIADH, CSW, dan DI. ${ }^{6,13}$

Dari seluruh kasus stroke akut pada penelitian ini yang terbanyak ialah jenis stroke hemoragik (53,7\%). Kemungkinan lebih tingginya kejadian stroke hemoragik dibandingkan iskemik ialah karena gejala dan tanda stroke hemoragik terjadi lebih akut dan berat. Dari keseluruhan kasus stroke akut ini, terdapat 30\% kasus dengan gangguan kadar natrium. Dari total gangguan ini, sebagian besar ditemukan pada kasus-kasus stroke hemoragik berdasarkan hasil brain CT-scan (56\%). Hal yang serupa juga ditemukan pada penelitian Siddiqui $^{7}$ yang mendapatkan adanya gangguan elektrolit terbanyak pada kasuskasus stroke hemoragik (62,2\%). Kusuda juga mendapatkan bahwa insidens gangguan elektrolit lebih banyak ditemukan pada stroke hemoragik (52\%). ${ }^{7}$

Pada penelitian ini rerata kadar natrium lebih rendah pada derajat defisit neurologik yang lebih berat. Berdasarkan skala NIHSS, pada defisit neurologik berat (NIHSS <4) didapatkan rerata kadar natrium $133 \mathrm{Meq} / \mathrm{L}$ dan pada defisit neurologik ringan (NIHSS >15) rerata kadar natrium $139 \mathrm{Meq} / \mathrm{L}$. Walaupun pada penelitian ini tidak ditemukan perbedaan bermakna dari kadar natrium berdasarkan berat-ringannya defisit neurologik, tetapi secara umum gangguan elektrolit meningkatkan risiko komplikasi pada stroke akut dan angka mortalitas. Disfungsi neurologik merupakan manifestasi utama dari gangguan elektrolit, terutama hiponatremia. Adanya kondisi patologi intrakranial akan memperbesar kemungkinan terjadinya disfungsi neurologik. ${ }^{14}$ Huang $^{10}$ mendapatkan angka mortalitas lebih tinggi pada stroke iskemik yang dikategorikan sindroma sirkulasi anterior total (TACS); dalam penelitian tersebut, TACS dikategorikan sebagai stroke berat.

Keterbatasan penelitian ini ialah: 1) Tidak dilakukan pemeriksaan kadar natrium ulangan saat keluar rumah sakit, sehingga tidak dapat diklarifikasi apakah gangguan natrium ini bersifat sementara atau menetap; 2) Tidak dilakukan pelacakan terhadap penyebab gangguan kadar natrium (misalnya dengan pemeriksaan osmolalitas urin), sehingga tidak dapat dibedakan antara SIADH dan CSW pada hiponatremia.

\section{SIMPULAN}

Dari hasil penelitian dapat disimpulkan bahwa insidens gangguan elektrolit pada stroke akut tinggi; sebagian besar berupa hiponatremia. Walaupun rerata kadar natrium terendah didapatkan pada defisit neurologik yang lebih berat, tidak ditemukan perbedaaan bermakna dengan kelompok lain. Tidak didapatkan hubungan bermakna antara skor GCS dengan gangguan natrium. 
Secara umum, gangguan kadar natrium dapat memengaruhi komplikasi dan angka mortalitas pada stroke akut. Deteksi dini gangguan kadar natrium dan manajemen yang tepat sangat berperan dalam keluaran pasien stroke akut.

\section{DAFTAR PUSTAKA}

1. WHO. The WHO stepwise approach to stroke surveillance/non communicable diseases and mental health. Geneva: WHO Press; 2005.

2. Misbach. Stroke: Aspek Diagnostik, Patofisiologi dan Manajemen. Jakarta: Perdossi Press; 2011.

3. Depkes. Indonesia bangun RS Pusat Otak Nasional [homepage on the Internet]. 2012 [updated 2012 Jul 14; cited 2013 Jan 12]. Available from: http:// www.depkes.go.id/index.php/berita/press -release/1705-indonesia-bangun-rumahsakit-pusat-otak-nasional-national-braincentre-hospital-.html.

4. Siddiqui MR, Islam QT, Haque MA, Iqbal MJ, Hossain A, Rahman YU, et al. Electrolyte status in different type of acute stroke patients and their correlation with some common clinical presentation. J Medicine. 2012;13:133-7.

5. Lath R. Hyponatremia in neurological diseases in ICU. Indian J Critical Care Med. 2005;9(1):47-50.

6. Aiyagari V, Deibert E, Diringer MN. Hypernatremia in the neurologic intensive care unit: How high is too high? Journal of Critical Care. 2006;21:163-72.

7. Siddiqui MR, Islam QT, Hague MA, Iqbal MJ, Hossain A, Rahman YU, et al. Dyselectrolytemia in acute stroke patients, an observational study.
Bangladesh J Medicine. 2011;22:30-4.

8. Eeuwijk P, Kepel B. Culture, health and poverty. Media Kesehatan. 2005; 1(2):67-75.

9. Kawilarang $\mathbf{H}$. Minahasa traditional food and beverages [homepage on the Internet]. 2008 [updated 2008 Apr 28; cited 2007 Oct 17]. Availabe from: www.theminahasa.net/social/tradition/fo od/index.

10. Huang WY, Weng WC, Peng TI, Chien YY, Wu CL, Lee M. et al. Association of hyponatremia in acute stroke stage with three-year mortality in patients with first-ever ischemic stroke. Cerebrovasc Dis. 2012;34:55-62.

11. Diaz JL, Granados M, Suarez JI. Management of medical complications in the neuroscience critical care unit. In: Suarez JI, editor. Critical Care Neurology and Neurosurgery. New Jersey: Humana Press Inc; 2004.

12. Donati-Genet PCM, Dubuis JM, Rimensberger PC. Acute symptomatic hyponatremia and cerebral salt wasting after head injury: An important clinical entity. Journal of Pediactric Surgery. 2001;36(1):1094-7.

13. Louzon P, DeRyke XL. Management of sodium abnormalities following cerebral insult [homepage on the Internet]. Nodate [cited 2013 Aug 15]. Available from: http://www.yumpu.com/en/docu ment/view/13735974/management-ofsodium-abnormalities-followingcerebral-insults-by-

14. Paiva WS, Bezzera DAF, Amorim RLO, Figueiredo EG, Tavarez WM, Andrade AF, et al. Serum sodium disorders in patients with traumatic brain injury. Therapeutics and Clinical Risk Management. 2011;7:345-9. 